удк 35-053.81(477)

DOI https://doi.org/10.32851/2708-0366/2020.4.15

Стукан T.M.

співробітник,

Херсонський державний аграрно-економічний університет ORCID: https://orcid.org/0000-0002-8682-1832

Stukan Tanya

Kherson State Agrarian and Economic University

\title{
МОЛОДІЖНА ПОЛІТИКА: \\ СУТЬ, ОСНОВНІ ПРИНЦИПИ ТА СТАН РЕАЛІЗАЦІЇ В УКРАЇНІ
}

\section{YOUTH POLITICS: ESSENCE, BASIC PRINCIPLES AND STATE OF REALIZATION IN UKRAINE}

\begin{abstract}
У статті визначено та виділено основні твердження науковців щзодо сутності поняття «молодіжна політика», приведено узагальнене трактування характеристики иьього терміна. Здійснено аналіз нормативно-правових актів украӥнського законодавства, цио регулює июю сферу діяльності у країні. Розкрито сутність принципів, на які спрямовано здійснення молодіжної політики, та визначено, щзо ие певні закономірності, які враховуються під час вжиття заходів, які безпосередньо спрямовані на виконання молодіжної політики на всіх етапах ї̈ реалізації. Визначено, щзо сьогодні в Україні діють три пріоритетні напрями в молодіжній політиці. 3 огляду на аналіз основних принципів молодіжної політики визначено низку кроків, які слід здійснювати на шляху створення на місиях та в новостворених об'єднаних територіальних громадах умов розвитку та самореалізації молоді.
\end{abstract}

Ключові слова: молодіжна політика, принципи, молодь, самореалізація, молодіжне підприємництво.

В статье определены и выделены основные утверждения ученых о сущности понятия «молодежная политика», приведень обобщенные трактовки характеристики этого термина. Осуществлен анализ нормативно-правовых актов украинского законодательства, регулируюшего эту сферу деятельности в стране. Раскрыта сущность принципов, на которые направлено осуществление молодежной политики, и определено, что это определенные закономерности, которые учитываются при принятии мер, которые непосредственно направлены на выполнение молодежной политики на всех ее этапах реализации. Определено, что сегодня в Украине действуют три приоритетных направления в молодежной политике. С учетом анализа основных принципов молодежной политики определен ряд шагов, которые следует осуществлять на пути создания на местах и в созданных объединенных территориальных общинах условий развития и самореализации молодежи.

Ключевые слова: молодежная политика, принципь, молодежь, самореализачия, молодежное предпринимательство.

Today, the paradigm and vector of development of regions and even the whole country is constantly changing, so it has been repeatedly confirmed that it all starts with the youth, as one of the main subjects of social and economic policy of the state. Youth is an important part of modern society, the bearer of the intellectual potential of the country and a determining factor of socio-economic progress. Therefore, today, local and national authorities are faced with the task of stopping the outflow of people aged 18 to 35 to other countries and creating appropriate conditions for young people to apply their acquired professional competencies in Ukraine. The implementation of this process should first of all begin through the implementation of an effective youth policy at the state level, which will be aimed at forming and stimulating the further development of youth entrepreneurship and take into account non-standard views of the world and preferences of young people. The article identifies and highlights the main statements of scientists on the essence of the concept of "youth policy", gives a generalized interpretation of the characteristics of this definition. The analysis of normative-legal acts of the 
Ukrainian legislation regulating this sphere of activity in the country is carried out. The main essence of the principles on which the implementation of youth policy is aimed is revealed and it is determined that these are certain regularities that are taken into account when implementing measures that are directly aimed at implementing youth policy at all stages of its implementation. It is determined that today in Ukraine there are three priority areas in youth policy. Also, based on the analysis of the basic principles of youth policy, a number of steps have been identified that should be taken to create conditions for the development and self-realization of youth on the ground and in the newly created united territorial communities. The priority components of the policy for the country should be financial and staffing, development of youth infrastructure, creation of conditions for youth entrepreneurship, as well as systematic involvement of young people in the process of development and decision-making.

Key words: youth policy, principles, youth, self-realization, youth entrepreneurship.

Постановка проблеми. У XXI сторіччі для кожної країни молодіжна політика має неабияке значення. Сьогодні повсякчас змінюються парадигма та вектор розвитку регіонів і навіть цілої країни, тому вже неодноразово було підтверджено, що це все починається з молоді як одного з головних суб'єктів соціальної та економічної політики держави. Молодь - це важлива частина сучасного суспільства, носій інтелектуального потенціалу країни та визначальний фактор соціально-економічного прогресу, тому сьогодні перед місцевими та загальнодержавними органами влади стоїть завдання спинити відтік людей віком від 18 до 35 років до інших країн світу та створити належні умови молоді для застосування набутих ними професійних компетентностей на території України. Реалізацію цього процесу перш за все слід почати через впровадження на державному рівні ефективної молодіжної політики, яка буде спрямована на формування та стимулювання подальшого розвитку молодіжного підприємництва, а також враховувати нестандартні погляди на навколишній світ та вподобання молодих людей. Україна за час своєї незалежності почала рух в цьому напрямі, але на цьому шляху виникає низка бар'єрів, які стримують цей процес щодо систематичного прогресивного розвитку, що спонукає до постійного перегляду основних підпунктів молодіжної політики з урахуванням передумов, у яких ії доводиться реалізовувати.

Аналіз останніх досліджень і публікацій. Вивченням обставин щодо формування молодіжної політики країни займалися такі вітчизняні вчені, як Є. Бородіна, М. Головатий, М. Головенько, М. Перепелиця. Крім того, стан реалізації в Україні молодіжної політики досліджено в працях таких українських науковців, як В. Барабаш, М. Дідух, Л. Кривачук, О. Кулик, С. Луценко, А. Мінаєв, К. Плоский, Ю. Поліщук, Н. Черниш, В. Шульга. Водночас зовнішнє та внутрішнє середовище функціонування молодіжного підприємництва перебуває в постійних змінах і трансформаціях, що спонукає до пошуку та застосування сучасних підходів у систематичному розвитку, удосконалення молодіжної політики як складової частини у формуванні та розвитку молодіжного підприємництва.

Формулювання цілей статті. Мета дослідження полягає в аналізі сутності поняття «молодіжна політика», розкритті його змісту та принципів як чинника розвитку молодіжного підприємництва, а також здійсненні всебічного оцінювання стану впровадження молодіжної політики в Україні.

Виклад основного матеріалу. Старт, від якого починається відлік становлення молодіжної політики в Україні, - це прийняття нормативно-правових документів, а саме Декларації про загальні засади державної молодіжної політики в Україні (1992 р.) та Закону України «Про сприяння соціальному становленню та розвитку молоді в Україні» (1993 р). Також до найбільш важливих законів, що регулюють молодіжну політику, належать Конституція України, Закони України «Про захист дитинства», «Про соціальну роботу з дітьми та молоддю», «Про забезпечення молоді, яка отримала вищу або професійно-технічну освіту, першим робочим місцем 3 наданням дотації роботодавцю», «Про забезпечення рівних прав між чоловіками та жінками», 
«Про молодіжні та дитячі громадські організації», «Про запобігання насильству у сім'ї», «Про державну підтримку сімей $з$ дітьми» та Сімейний кодекс України. Саме в цих нормативних актах прописані молодіжна стратегія, іiі цілі, пріоритети, заходи, щодо досягнення цільових результатів та визначені джерела фінансового забезпечення.

Молодіжна політика - це структурно вибудована модель розвитку на всіх рівнях: від державного до врахування інтересів людей віком від 18 до 35 років. Вона включає набір правил, методів та принципів, які спонукають молодих людей проявляти ініціативу, самостійно визначати власні цілі та цінності, бути залученими й мати змогу визначати пріоритети і методи здійснення молодіжного підприємництва в країні. Важливо також те, щоби молодіжна політика на етапі, коли люди вирішили займатися молодіжним підприємництвом, була ще спрямована на підтримання рівня соціальної безпеки, попередження та подолання складнощів, з якими може зіштовхнутися молодь у цьому процесі.

Наукове трактування поняття «молодіжна політка» наведено в табл. 1.

\section{Трактування сутності поняття «молодіжна політика»}

Таблиця 1

\begin{tabular}{|l|l|}
\hline \multicolumn{1}{|c|}{ Автор } & \multicolumn{1}{c|}{ Визначення поняття } \\
\hline В. Криворученко & $\begin{array}{l}\text { Перелік ідей, теоретичних положень про роль і місце молоді, а також за- } \\
\text { ходи практичної діяльності держави, громадських організацій та інших } \\
\text { соціально-економічних інституцій щодо реалізації ідей, положень, прин- } \\
\text { ципів, завдань задля формування й розвитку молоді та молодіжного під- } \\
\text { приємництва. }\end{array}$ \\
\hline М. Головатий & $\begin{array}{l}\text { Специфічний і пріоритетний напрям діяльності державних органів влади, } \\
\text { який спрямований на створення умов і соціальних гарантій для соціаль- } \\
\text { ного становлення та розвитку молоді, їх самореалізації як в особистих, } \\
\text { так і в суспільних інтересах. }\end{array}$ \\
\hline $\begin{array}{l}\text { Н. Корпач, } \\
\text { I. Сидорук }\end{array}$ & $\begin{array}{l}\text { Політика, що спрямована на вирішення питань виховання, освіти, праці, } \\
\text { побуту, відпочинку, духовного та фізичного розвитку молоді з подальшою } \\
\text { іх реалізацією у певному виді діяльності. }\end{array}$ \\
\hline
\end{tabular}

Джерело: сформовано за даними джерел [1; 4; 5]

Узагальнюючи наведений перелік визначень сутності поняття «молодіжна політика» кожним з авторів, можемо сказати, що це вид діяльності держави та інших іiі формальних та неформальних інституцій, які об'єднують та спрямовують зусилля на створення соціальних, економічних, фінансових, громадських умов та гарантій, у яких молодь може себе самореалізувати в соціумі, отримуючи бажаний ефект. Молодіжна політика має бути спрямована на створення можливостей для розвитку та отримання необхідних знань для того, щоби молода людина стала конкурентоздатною на ринку праці своєї країни.

Декларація про загальні засади державної молодіжної політики в Україні дає тлумачення державної молодіжної політики як системної діяльності усіх гілок влади у відносинах з особистістю, молоддю, молодіжним рухом, що ставить перед собою мету створення соціально-економічних, політичних, організаційних, правових умов та гарантій для самовизначення, інтелектуального, морального, фізичного розвитку молоді, реалізації іiі творчого потенціалу перш за все у власних інтересах, а також в інтересах цілої країни [2].

Зміст молодіжної політики як складової частини з реалізації молодіжного підприємництва розкривається через сукупність принципів. Це закономірності, які враховуються під час вжиття заходів, які безпосередньо спрямовані на виконання молодіжної 
політики на всіх етапах іiі реалізації. Принципи молодіжної політики, на яких вона базується, схематично відображені на рис. 1, вони взаємопов'язані та доповнюють один одного.

Здійснення молодіжної політики передбачає перш за все рівноправність всіх її учасників, що регулюється принципом рівноправності молоді, який не допускає надання привілеїв чи встановлення обмежень за ознаками кольору шкіри, раси, політичних, релігійних та інших переконань, статі, віку, етнічного та соціального походження, громадянства, сімейного та майнового стану, мови, місця проживання тощо. Перш ніж починати будь яку діяльність, слід вивчити та проаналізувати зовнішні та внутрішні фактори, які можуть вплинути на процес, розглянути міжнародний досвід, якщо він позитивний, застосувати його, за що відповідає принцип обгрунтованості, який також передбачає врахування статистичної інформації, соціологічних досліджень та формування загальної стратегії, зокрема, щодо того, в якому напрямі буде відбуватися реалізація молодіжної політики.

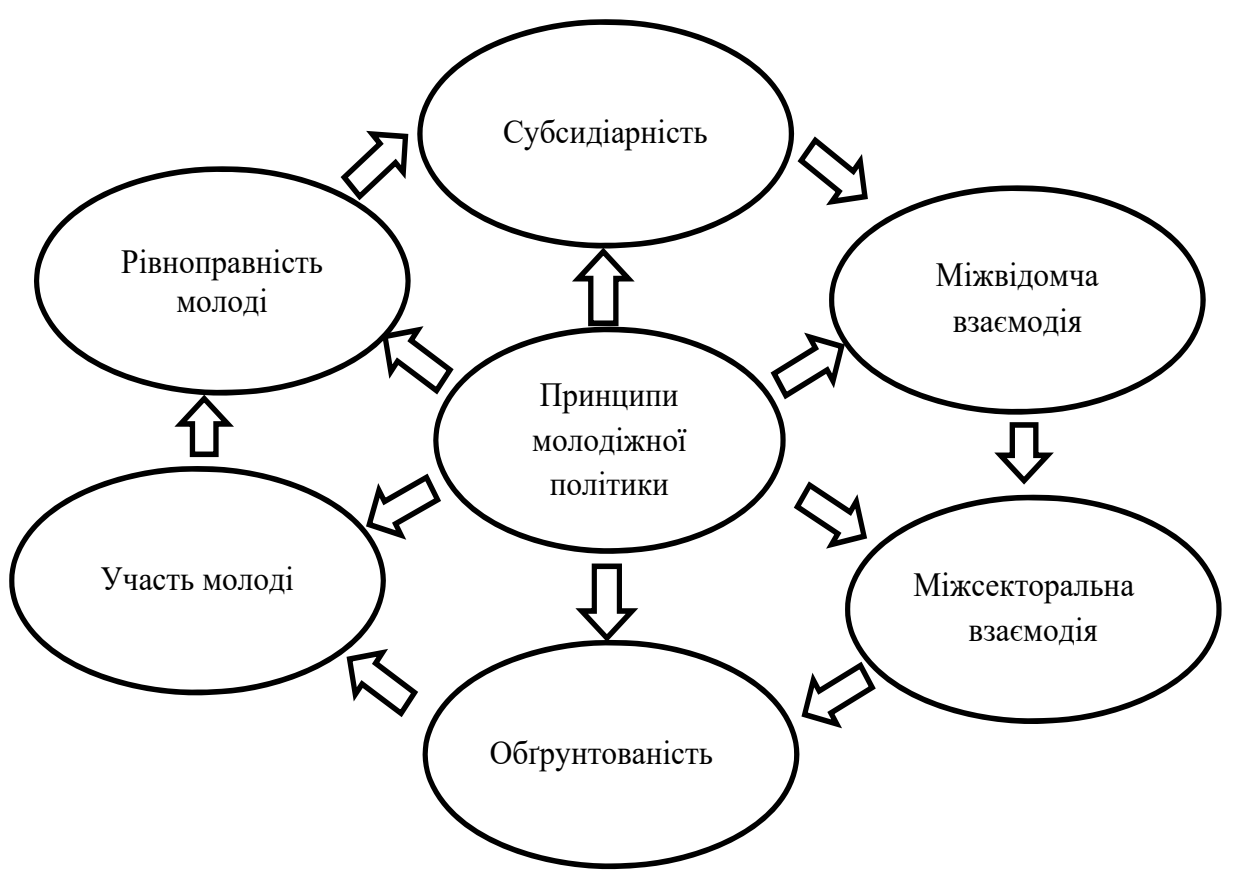

Рис. 1. Основні принщипи молодіжної політики

Джерело: сформовано за даними [3]

Принцип міжвідомчої та міжсекторальної взаємодії - це залучення органів виконавчої влади, місцевого самоврядування, громадських і міжнародних організацій, інших зацікавлених сторін до формування та реалізації молодіжної політики. Цей принцип обумовлює те, що отримання швидкого ефекту та досягнення поставлених цілей є можливими за умови спільної взаємодії всіх без винятку учасників, які долучені до реалізації молодіжної політики, кожен з яких розуміє свою частку відповідальності за майбутній результат. Вважаємо, що важливим принципом на рис. $1 €$ участь молоді, оскільки впроваджувати молодіжну політику без молоді як головного учасника неможливо, тому виникає потреба у встановленні механізмів із залучення молоді до формування та реалізації молодіжної політики через спонукання до самоор- 
ганізації, іiі заохочення до волонтерської діяльності. Принцип субсидіарності передбачає надання в процесі реалізації молодіжної політики достатніх повноважень та ресурсів на той рівень, від якого буде отриманий бажаний результат та максимальний ефект для кожного із суб'єктів. Охарактеризувавши наведені принципи, ми визначили, що вони є основоположними базисами, які у ході реалізації молодіжної політики в країні можуть свідчити про наявність сильних чи слабких сторін щодо її впровадження.

Молодіжна політика в Україні сьогодні у своєму розвитку має три пріоритетні напрями, на які спрямовані всі її принципи, такі як зайнятість молоді, здоровий спосіб життя та патріотичне виховання (рис. 2).

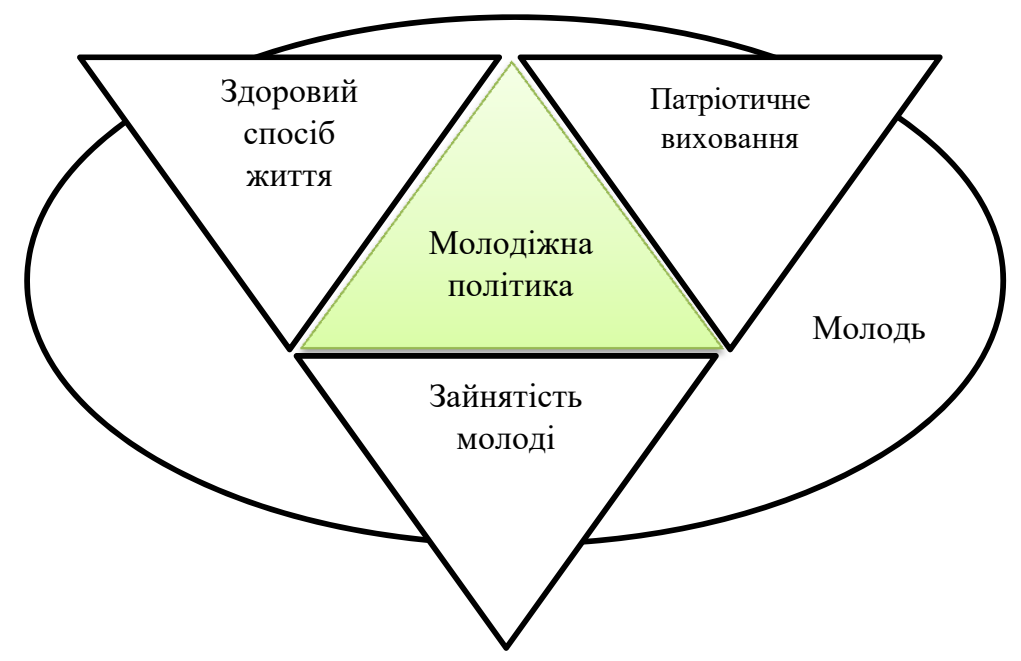

Рис. 2. Пріоритетні напрями розвитку молодіжної політики в Україні Джерело: сформовано за даними [6]

На рис. 2 відображені базові сфери, щодо яких сьогодні здійснюється реалізація молодіжної політики в Україні. Така їх обмеженість обумовлена недосконалістю законодавчої бази, що регулює реалізацію молодіжної політики та недостатність або взагалі відсутність фінансового забезпечення. Водночас це не може стати перепоною, а вимагає здійснення розгляду та застосування інших напрямів у цій політиці, які зможуть підсилити наявні та відкрити нові перспективні можливості щодо долучення молоді. Слід розробити та впровадити ефективні загальнодержавні довгострокові комплексні молодіжні програми, стратегію щодо розвитку різних напрямів молодіжної політики, отже, сформувати стандарти у здійсненні молодіжної роботи, які будуть включати набір конкретних практичних заходів та дій, що призведуть до отримання бажаного ефекту.

Висновки. Молодіжна політика є одним 3 пріоритетних напрямів ефективного розвитку економіки країни. Це формування комфортного середовища для життя, розвитку, зайнятості молоді, яке дасть їй змогу розвивати себе на місцях, там, де вона проживає чи має бажання жити. Пріоритетними складовими частинами цього мають стати фінансове та кадрове забезпечення, розвиток молодіжної інфраструктури, створення умов для молодіжного підприємництва, а також залучення людей віком від 18 до 35 років до процесу розроблення та ухвалення рішень.

Сьогодні молодь бажає бути дотичною до всіх процесів, які відбуваються в державі, а з огляду на карантинні умови, що склалися у 2020 році, люди від 18 до 35 років намагаються реалізувати себе в тій місцевості, де вони проживають. В цей процес слід 
активно включитися з боку держави молодіжним центрам, які мають стати осередками практичної роботи з молоддю, які сприяють їх розвитку, громадянській освіті, популяризації здорового способу життя, волонтерства, молодіжного підприємництва, підвищенню рівня внутрішньої мобільності. Такі центри треба створювати в кожній громаді на базі закладів освіти, культури, спорту у вигляді молодіжних хабів, платформ та коворкінг-майданчиків, через них слід просувати та реалізовувати молодіжну політику, а також ії принципи, розширювати напрями, в яких молодь може себе знайти в соціумі, отже, брати участь у розвитку в країні перспективних видів діяльності, в яких вона безпосередньо зможе себе реалізувати. Сьогодні до інвестиційно привабливих видів економічної діяльності, де молодь зможе знайти себе, віднесено виробництво одягу, харчових і фармацевтичних продуктів, комп'ютерів, електронної та оптичної продукції, текстильне виробництво, виробництво електричного устаткування та меблів, вирощування однорічних та дворічних культур, наземний транспорт, комп'ютерне програмування.

3 огляду на аналіз основних принципів молодіжної політики виникає потреба визначення та встановлення чітких кроків щодо її впровадження на місцях та в новостворених об'єднаних територіальних громадах. До цих кроків слід віднести такі:

1) розроблення програми розвитку молоді, формування іï бюджету та календарного плану;

2) організація заходів з надання послуг для молоді та створення необхідної молодіжної інфраструктури;

3) впровадження молодіжної кадрової політики (стажування, підвищення кваліфікації, тренінги щодо першого робочого місця, профорієнтація серед шкільної молоді тощо);

4) встановлення фінансових стимулів у вигляді премій, соціального житла для тих, хто займається молодіжним підприємництвом, запровадження компенсації відсотків по кредитах, видача безвідсоткового кредиту, пільги на оренду приміщень, землі тощо;

5) проведення щорічного звітування за результатами роботи в напрямі молодіжної політики задля аналізу загального стану та виявлення сильних і слабких сторін для їх посилення та визначення перспективних напрямів роботи.

Водночас успішна реалізація засад молодіжної політики є можливою лише за умови об'єднання спільних зусиль державної влади усіх рівнів, громадськості, неформальних спільнот, підприємців, науковців та безпосередньо самої молоді, тільки за цієї умови можна подолати виклики, з якими доводиться стикатися молодій людині в процесі своєї професійної та соціальної реалізації.

\section{Список використаних джерел:}

1. Головатий М. Державна молодіжна політика як феномен суспільного розвитку і нова парадигма державотворення у країнах перехідного періоду. Актуальні проблеми державного управління : збірник наукових пращь. Вип. 10. Одеса : ОРІДУ УАДУ, 2002. С. 291-304.

2. Про загальні засади державної молодіжної політики в Україні : Декларація. URL: https://zakon.rada.gov.ua/laws/show/2859-12\#Text (дата звернення: 04.12.2020).

3. Про сприяння соціальному становленню та розвитку молоді в Україні : Закон України від 23 березня 2000 року № 1613-III (1613-14). URL: http://zakon3.rada.gov.ua/laws/show/2998-12 (дата звернення: 04.12.2020).

4. Корпач Н., Сидорук І. Основні напрями реалізації державної молодіжної політики в Україні: соціально-педагогічний аспект. Педагогічний часопис Волині. 2016. № 2. С. 30-34.

5. Криворученко В. К вопросу о законодательстве субъектов в сфере молодежной политики. Киев : НИЦ ПМ, 1990. 125 с.

6. Становище молоді в Україні : аналітичний звіт. URL: http://www.un.org.ua/images/ documents/4790/THE\%20STATE\%20OF\%20YOUTH\%20IN\%20UKRAINE\%202019\%20 \%D1\%83\%D0\%BA\%D1\%80.pdf (дата звернення: 04.12.2020). 


\section{References:}

1. Golovaty M. (2002) Derzhavna molodizhna politika yak fenomen suspil'nogo rozvitku i nova paradigma derzhavotvorennya u kraïnah perekhidnogo periodu [State youth policy as a phenomenon of social development and the new paradigm of state formation in transition countries]. Aktual'ni problemi derzhavnogo upravlinnya. Odesa: ORIDU UADU, no. 10, pp. 291-304.

2. Declaration "On the General Principles of State Youth Policy in Ukraine". From 15.12.1992. № 2859-XII. Available at: https://zakon.rada.gov.ua/laws/show/2859-12\#Text (accessed 04 December 2020).

3. Law of Ukraine "On promoting the social formation and development of youth in Ukraine". From 23.03.2000 № 1613-III (1613-14). Available at: http://zakon3.rada.gov.ua/laws/show/2998-12 (accessed 04 December 2020).

4. Korpach N., Sidoruk I. (2016) Osnovni napryami realizaciï derzhavnoï molodizhnoï politiki v Ukraïni: social'no-pedagogichnij aspekt [Basic directions of realization of state youth policy in Ukraine: socio-pedagogical aspect]. Pedagogical magazine of Volyn, no. 2, pp. 30-34.

5. Krivoruchenko V. (1990) K voprosu o zakonodatel'stve sub'ektov v sfere molodezhnoj politiki [On the issue of the legislation of the subjects of the in the field of youth policy]. Kiev: SIC PM. (in Russian)

6. Stanovyshhe molodi v Ukrajini : analitychnyj zvit [The situation of youth in Ukraine : an analytical report]. Available at: http://www.un.org.ua/images/documents/4790/THE\%20STATE \%20OF\%20YOUTH\%20IN\%20UKRAINE\%22019\%20\%D1\%83\%D0\%BA\%D1\%80.pdf (accessed 04 December 2020). 